\title{
Genotype by Environment Interaction for Yield and Somatic Cell Score with Alternative Environmental Definitions
}

\author{
E. Raffrenato, ${ }^{\star} †$ R. W. Blake,† P. A. Oltenacu, $†$ J. Carvalheira,‡ and G. Licitra* \\ ${ }^{*}$ CoRFiLaC, Regione Siciliana, 97100 Ragusa, Italy \\ †Department of Animal Science, Cornell University, Ithaca, 14853 \\ ‡ Instituto de Ciências Biomédicas Abel Salazar and Centro de Investigação em Biodiversidade e Recursos Genéticos, \\ Universidade do Porto, 4485-661 Vairão, Portugal
}

\begin{abstract}
Differential genetic expression in high and low opportunity Sicilian Holstein-Friesian and Brown Swiss herd environments was investigated using endogenous and exogenous variables in a set of three definitions. Results of genetic by environmental interaction were compared using alternative environmental definitions: within herd-year standard deviation for mature equivalent milk yield (HYSD), detectable incidence of normal vs. abnormal (peakless) lactation and herds clustered by causal relationships from high and low frequency use of nutrition, milking, health and animal handling practices. Data for genetic analysis consisted of first-lactation standardized yields of milk, fat and protein, and weighted somatic cell score for 8897 daughters of 825 Holstein-Friesian sires and 1143 daughters of 220 Brown Swiss sires. Components of covariance, heritabilities, and genetic correlations were estimated using bivariate and multivariate sire models for average and contrasting environments for each definition. Sire variances for yields were consistently smaller in the low opportunity environments of both breeds. Except for differential incidence of abnormal lactation in Friesian herds, correlated yield response in less privileged environments was 0.41 to 0.81 as much as in high opportunity environments, a substantial loss. Genetic correlations between HYSD environments for yield traits of Friesian were 0.48 to 0.66 but exceeded 0.80 for other definitions. Less correlated response in somatic cell score was also predicted for environments with low use of yield-enhancing practices ( 0.66 for Friesian and 0.61 for Brown Swiss), which may have resulted from less health care and poorer milking management. Therefore, unfavorable management interactions likely foster unequal gains from selection in contrasting environments defined exogenously or by incidence of peakless lactation. Conversely, greater genetic as well as pheno-
\end{abstract}

Received October 16, 2002.

Accepted February 18, 2003.

Corresponding author: E. Raffrenato; e-mail: er53@cornell.edu. typic response is expected from additional inputs of nutrition, health care and milking management.

(Key words: genotype $\times$ environment interaction, heterogeneous genetic variance, milk yield, environmental definitions)

Abbreviation key: $\mathbf{G} \times \mathbf{E}$ = genotype by environment interaction, HYSD = herd-year standard deviations, ME $=$ Mature equivalent, WSCS $=$ weighted somatic cell score.

\section{INTRODUCTION}

Potential genotype by environment interaction $(\mathbf{G} \times \mathbf{E})$ in milk production has been mostly studied with environments arbitrarily defined by country, region, and herd phenotypic performance. Two criteria especially have been used to discriminate productive opportunity: herd mean milk yield per cow and its phenotypic variance. Kolmodin and co-workers (2002) recently used herd-year mean performance to define a continuous environmental gradient, or reaction norm, to circumvent limitations of genetic connectedness between countries, which potentially enhances the likelihood of detecting $\mathrm{G} \times \mathrm{E}$. However, differentiation by mean yield is analogous to selection on herd means, which may result in biased estimates of genetic and residual variances (Famula, 1989). Within herd-year-season or herd-year standard deviations (HYSD) for milk yield have usefully discriminated herd environments in various geographic regions because heterogeneous phenotypic variances consistently predisposed unequal genetic responses, presumably because productive opportunity varies accordingly (Carvalheira et al., 1998; Cienfuegos-Rivas et al., 1999; Costa et al., 2000; Short et al., 1990; Stanton et al., 1991b; Meinert et al., 1988; Meinert et al., 1992). A drawback of HYSD definition of production environments is that it relies on an endogenous variable potentially correlated with yield response (i.e., the outcome). Production conditions also have been characterized by clustering herds primarily by endogenous descriptors (e.g., HYSD, peak yield, days to peak yield, herd size) to predict sire breeding values 
for alternative systems but only heritabilities and genetic correlations were reported (Weigel and Rekaya, 2000; Zwald et al., 2001). We are unaware of reports of genetic components of covariance and expected correlated responses for contrasting environments defined by causal relationships (e.g., inputs and practices) with animal response.

Licitra and collaborators (1998) found substantial peakless lactations in herds in Mediterranean southeastern Sicily (Italy) lacking normal detectable ascent to peak milk yield followed by a rapid (convex) decline. These abnormal outcomes signified substantial sacrifices in milk production with restricted within-herd variation. Potential causes of opportunity loss in milk were inadequate diet from low availability and poor quality of forage, insufficient reserves of body tissues to support early lactation, and inadequate health management. Extending the results from other studies to this Sicilian case, where genetic parameters of dairy production have not yet been estimated, the unequal input use (environmental opportunity) associated with abnormal lactation would be expected to underwrite significant $\mathrm{G} \times \mathrm{E}$ in dairy performance.

Therefore, the objectives of this study were to evaluate potential $\mathrm{G} \times \mathrm{E}$ in yields of milk, fat and protein, and in somatic cell scores of Friesian and Brown Swiss cows by comparing genetic parameters and expected correlated responses in contrasting Sicilian herd environments alternatively defined. Farmers need to know the opportunity losses in daughter response due to management inputs, which are known to influence selection decisions (Holmann et al., 1990; Blake, 1992).

\section{MATERIALS AND METHODS}

\section{Data and Edits}

Mature equivalent (ME) lactation yields of milk, fat and protein and pedigree files were provided by the Italian Friesian Association (Associazione Nazionale Frisona Italiana) and the Italian Brown Swiss Association (Associazione Nazionale Allevatori Razza Bruna). Initial data comprising 39,030 records from 16,259 Friesian cows and 8685 records from 3430 Brown Swiss cows calving from January 1994 to December 1999 were edited for redundant and incomplete observations, lactations initiated by abortion, missing cow identification, pedigree errors, incorrect or inconsistent lactation number, age and date of calving and calving interval. Primiparous cows were 18 to 45 mo of age at calving. Herds with less than three records per herd-year and sires with less than two daughters were discarded. The final data for genetic analysis contained 8897 primiparous daughters of 825 Friesian sires and 1143 primiparous daughters of 220 Brown Swiss sires.
Test day milk yields and somatic cell counts of the first three lactations were provided by CoRFiLaC, Sicily's main dairy research center, and the Associazione Provinciale Allevatori of Ragusa, Sicily. At least four test day records were required per lactation. Observations for DIM less than 5 or greater than 310 and intervals less than $15 \mathrm{~d}$ or greater than $75 \mathrm{~d}$ between observations were not considered. Weighted SCS (WSCS) per lactation was created from the monthly somatic cell scores for each cow with at least one SCC. SCS, which is homoscedastic among samples, was calculated for each SCC observation as: $\left(\log _{\mathrm{e}} \mathrm{SCC} / \log _{\mathrm{e}} 2\right)-\left(\log _{\mathrm{e}} 12.5 /\right.$ $\left.\log _{\mathrm{e}} 2\right)+12$. Because SCC is inversely related to daily milk yield (Jones et al., 1984), the WSCS was calculated using test day milk $\left(\mathrm{m}_{\mathrm{i}}\right)$ associated with $\mathrm{SCS}$ as a weighting factor:

$$
\text { WSCS }=\frac{\sum_{\mathrm{i}=1}^{\mathrm{n}}\left(\mathrm{m}_{\mathrm{i}} \mathrm{SCS}_{\mathrm{i}}\right)}{\sum_{\mathrm{i}=1}^{\mathrm{n}} \mathrm{m}_{\mathrm{i}}} .
$$

Data on management practices were from interviews with a special questionnaire (Raffrenato, 2002) of 168 Friesian and 71 Brown Swiss herd owners conducted in 2000 through CoRFiLaC. The survey included $82 \%$ of the Friesian and $86 \%$ of the Brown Swiss herds enrolled in the local dairy recording program (Associazione Provinciale Allevatori), the majority of the populations of herds for these breeds in Sicily's primary milk shed.

\section{Definitions of Contrasting Herd Environments}

Within herd-year standard deviation for lactation milk yield. The phenotypic HYSD for 305-day ME milk yield was used to discriminate herds like in other studies (Boldman and Freeman, 1990; Dong and Mao, 1990; Stanton et al., 1991a; 1991b; Cienfuegos-Rivas et al., 1999; Costa et al., 2000). Low opportunity environments had HYSD $<1330 \mathrm{~kg}$ for Friesian herds and HYSD $<950 \mathrm{~kg}$ for Brown Swiss herds. High opportunity environments were HYSD $>1370 \mathrm{~kg}$ for Friesian herds and HYSD $>990 \mathrm{~kg}$ for Brown Swiss herds. Accordingly, 132 Friesian herds and 37 Brown Swiss herds were allocated to the low HYSD class, and 76 Friesian and 30 Brown Swiss herds were allocated to the high class. There were 315 (of 825) Friesian sires and 63 (of 220) Brown Swiss sires with recorded daughters in both HYSD environments.

Detectable peak daily milk yield. Data files of test day milk records were obtained for cows in two parity groups: cows in first lactation and those in second and third lactations. The days in milk observations for these 
records were divided into 31 classes for 18 age-at-calving groupings. The final data sets consisted of 195,705 records for 228 Friesian herds and 39,916 records for 78 Brown Swiss herds. Solutions were obtained with the following mathematical model for each DIM class for each parity group in each herd:

$$
\mathrm{y}_{\mathrm{ijklmn}}=\mathrm{HYS}_{\mathrm{i}}+\operatorname{Age}_{\mathrm{j}}\left(\mathrm{H}_{\mathrm{k}}\right)+\operatorname{DIM}_{\mathrm{m}}\left(\mathrm{H}_{\mathrm{k}} \mathrm{P}_{\mathrm{l}}\right)+\mathrm{e}_{\mathrm{ijklmn}},
$$

where $y_{i j k l m n}$ is the $n$th test day observation at herdyear-season i, age at calving class $\mathrm{j}$, herd $\mathrm{k}$, parity $\mathrm{l}$ and DIM class $\mathrm{m}$; $\mathrm{HYS}_{\mathrm{i}}$ is the level i for the herd-year-season fixed effect; Age $_{j}\left(\mathrm{H}_{\mathrm{k}}\right)$ is the level $\mathrm{j}$ of the fixed effect for age at calving nested within each herd; $\operatorname{DIM}_{m}\left(\mathrm{H}_{\mathrm{k}} \mathrm{P}_{1}\right)$ is the $m$ th level of the fixed effect for DIM nested within herd and parity; and $\mathrm{e}_{\mathrm{ijk} \mathrm{klm}}$ is the random vector of residuals assumed to be normally distributed. Relationships among animals were ignored.

The DIM solutions for each herd and parity class were fit to an incomplete gamma function $\left(\mathrm{y}=a \mathrm{t}^{\mathrm{b}} \mathrm{e}^{-\mathrm{ct}}\right.$; Wood, 1967). Only cows with at least five test day records per lactation were analyzed. Herds permitting estimation for only one parity class were ignored to restrict classification errors. Detectable peak lactation was determined by testing the significance and sign of the $b$ parameter using a significance threshold of $\alpha$ $=0.05$.

High opportunity Friesian herds were those with detectable peak lactation (i.e., $b$ parameter value exceeded zero; $P<0.05)$ in primiparous and multiparous cows. Low opportunity Friesian herds were those with abnormal lactation in either parity group (i.e., $b$ parameter value less than or not significantly different from zero). Low opportunity Brown Swiss herds were those with abnormal lactation in both parity groups, otherwise herds were assigned to the high environment. This response behavior would be expected to differentiate productive opportunity by nutritional and health inputs and orchestrated physiological, or homeorhetic, drivers of lactation. As a result there were 91 Friesian herds and 38 Brown Swiss herds in the low opportunity environment, and 136 Friesian and 38 Brown Swiss herds in the high environment. Similar proportions of herds were sought in the contrasted environments to assure sire representation and genetic ties between them.

Management practices that enhance milk production. Interviews of owners indicated there were no important changes in herd management across the time period covered by the lactation performance data. Therefore, survey responses to 17 questions about management inputs (Table 1) were used to form environmental clusters with contrasting input use frequencies. Input categories included nutrition management, milking practices, health practices, and animal handling.
Table 1. Survey questions about input use to discriminate herd productive opportunities.

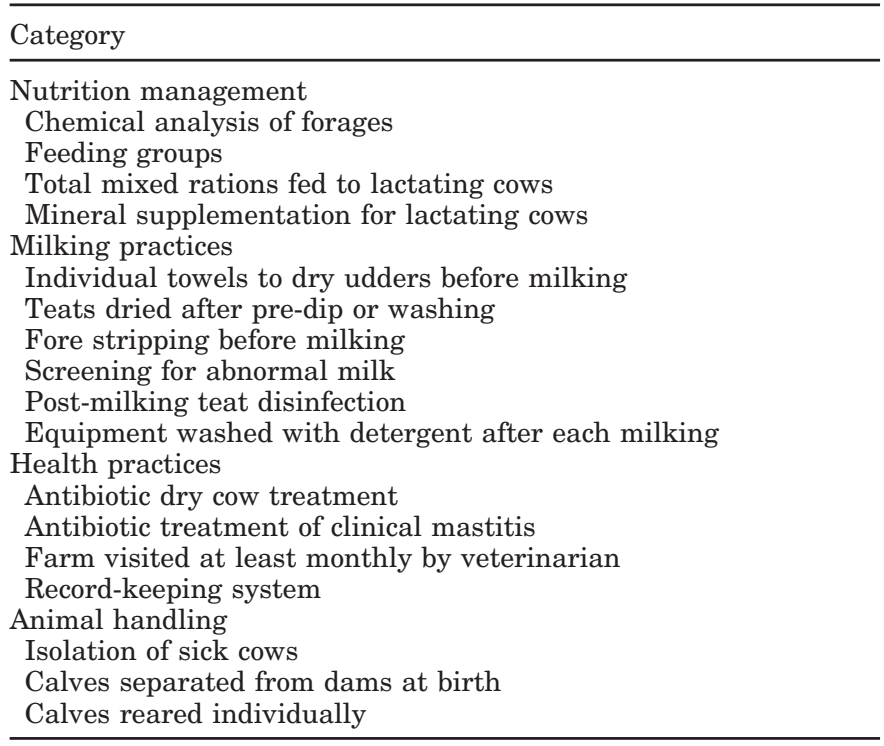

Each practice was assigned an asymmetric binary value ( $0=$ no, $1=$ yes) whether it would be expected to enhance milking performance. The management environmental distance of Jaccard (Kuo, 1997) between two farms, x and $\mathrm{y}$, was calculated as

$$
d(x, y)=\frac{\sum_{i=1}^{n} \delta_{x, y}^{i}}{\sum_{i=1}^{n} v_{x, y}^{i}+\sum_{i=1}^{n} \delta_{x, y}^{i}}
$$

where $n=$ total number of questions considered, $\delta_{\mathrm{x}, \mathrm{y}}=$ 1 if $\mathrm{x}_{\mathrm{i}} \neq \mathrm{y}_{\mathrm{i}}, \delta_{\mathrm{x}, \mathrm{y}}=0$ otherwise and $\mathrm{v}_{x, y}=1$ if $\mathrm{x}_{\mathrm{i}}=\mathrm{y}_{\mathrm{i}}, \mathrm{v}_{x, y}$ $=0$ otherwise. By this method a specified practice is weighted more than its absence. The resulting matrices of management distances between farms were used to form two groups of herds in each breed using the flexible beta clustering method (Lance and Williams, 1967), where the value of beta governs the distance between points merged into a cluster. A beta value of -0.25 was used as recommended for conditions of variable response and widely spaced clusters (Milligan, 1989). In our case this hierarchical agglomeration method signified similar causality in each environment, or predisposing dietary adequacy, udder health and other conditions affecting yield response. This criterion resulted in 95 Friesian and 27 Brown Swiss herds in the low environment, and 73 Friesian and 44 Brown Swiss herds in the high environment.

Some herds were classified as providing the same general opportunity with our definitions. For example, there were 68 Friesian herds and 22 Brown Swiss herds 
common to the low HYSD and abnormal lactation environments; and 37 Friesian and 16 Brown Swiss herds with abnormal lactation and infrequent use of yieldenhancing practices. This set of criteria identified the same 25 (37) Friesian herds and 8 (6) Brown Swiss herds common to the low (high) environments.

\section{Within-Environment Analysis}

The components of variance and covariance and genetic parameters for first-lactation yields of milk, fat and protein, and weighted somatic cell score in each breed were estimated using a multiple-trait linear mixed sire model with unequal design matrices and a missing observations structure. All traits were analyzed for the average herd (all data) and low and high opportunity environments.

The model in matrix notation was:

$$
\mathrm{Y}=\mathrm{Xh}+\mathrm{ZQg}+\mathrm{Zs}+\mathrm{e},
$$

where $\mathrm{Y}=$ vector of records of traits within an environment; $\mathrm{h}$ = fixed herd-year-season effects; $\mathrm{X}=$ incidence matrix relating herd-year-season to records; $\mathrm{ZQ}=$ incidence matrix relating group of sires to daughters' records; $g$ = fixed genetic group effects; $Z$ = incidence matrix relating sires to daughters' records; $\mathrm{s}=$ vector of random sire effects; and e = vector of random errors. Assumptions were:

$$
\begin{aligned}
& \mathrm{E}(\mathrm{Y})=\mathrm{Xh}+\mathrm{ZQg} \\
& \mathrm{E}(\mathrm{s})=\mathrm{E}(\mathrm{e})=0 \\
& \mathrm{~V}(\mathrm{e})=\mathrm{I} \sigma_{\mathrm{e}}^{2}=\mathrm{R}_{\mathrm{o}} \otimes \mathrm{I}=\mathrm{R} \\
& \mathrm{V}(\mathrm{s})=0.25 \sigma_{\mathrm{s}}^{2} \otimes \mathrm{A}=\mathrm{G}_{\mathrm{o}} \\
& \mathrm{Cov}(\mathrm{s}, \mathrm{e})=0,
\end{aligned}
$$

where $\otimes=$ refers to the Kronecker product; $G_{0}=$ the genetic variance-covariance matrix; $R_{0}=$ the environmental variance-covariance matrix; $\mathrm{V}(\mathrm{e})=$ the residual variance.

\section{Between-Environment Analysis}

Components of covariance and genetic correlations between environments were estimated for each trait in each breed using a two-trait linear mixed sire model with unequal design matrices. This model was the same as for the within-environment analysis with identical assumptions. The size of $\mathrm{A}$ for the respective breeds was the same for every analysis regardless of environmental definition.

\section{Correlated Response and Genetic Trend}

Coefficients of correlated response in low opportunity environments from sire selection in the high opportu- nity environment were estimated by genetic regression $\hat{\sigma}_{\mathrm{ij}} / \hat{\sigma}_{j}^{2}$, where $\hat{\sigma}_{\mathrm{ij}}$ is the estimate of sire covariance for pairs of traits in the contrasting environments and $\hat{\sigma}_{\mathrm{j}}^{2}$ is the estimate of sire variance in the high opportunity herds.

Genetic trends in contrasting environments were estimated for each trait and breed by regression of the weighted (by number of daughters per sire) average sire predicted transmitting ability (PTA) on year of birth of their progeny. These PTA were obtained from the between-environment analysis by adding sire solutions from the mixed model equation to respective group solutions in the same system of equations. Average PTA was expressed as a deviation from the mean PTA of cows born in 1991.

\section{RESULTS AND DISCUSSION}

\section{Low and High Opportunity Environments}

Table 2 contains descriptive statistics for average herds (all data) and HYSD environments for Friesian and Brown Swiss cows. The HYSD definition of contrasting environments excluded 20 Friesian and 11 Brown Swiss herds to restrict overlap between them. One Friesian herd and two Brown Swiss herds were excluded for missing information to determine peak lactation. Sixty Friesian and seven Brown Swiss herds could not be clustered by management practices because they were no longer operating at the time of the survey.

\section{Within-Environment Analysis}

Yields of milk, fat, and protein. Components of covariance for yields of milk in contrasted environments are in Table 3 for Friesian cows and in Table 4 for Brown Swiss cows. Sire and residual variances were smaller in low than in high opportunity environments of both breeds. This compression of variance was like that observed in diverse situations in North America and Latin America (Castillo et al., 2000; Costa et al., 2000; Cienfuegos-Rivas et al., 1999; Dong and Mao, 1990; Meinert et al., 1988; Stanton et al., 1991b). The resulting heritabilities ranged from 0.21 to 0.28 in the two breeds, which, like the associated correlations (Raffrenato, 2002), were similar to other published estimates (Castillo et al., 2000; Costa et al. 2000; DeJager et al., 1987; Maijala et al., 1974; Manfredi et al., 1984; Roman and Wilcox, 2000; Seykora and McDaniel, 1983; Schutz et al., 1990; Welper et al., 1992). Unfortunately, components of covariance from a national study of Italian Friesian (Burnside et al., 1992) were not published, which precluded comparison with our results. 
Table 2. Numbers of records, herds and sires, and means and standard deviations for mature equivalent (ME) yields of milk, fat and protein, and weighted somatic cell score for the average herd (mean of all data) and for low and high herd-year standard deviation (HYSD) environments for Friesian and Brown Swiss cows.

\begin{tabular}{|c|c|c|c|c|c|c|}
\hline & \multicolumn{3}{|c|}{ Friesian $^{1}$} & \multicolumn{3}{|c|}{ Brown Swiss ${ }^{2}$} \\
\hline & Average & Low & High & Average & Low & High \\
\hline Records & 8897 & 3753 & 4532 & 1143 & 467 & 556 \\
\hline Herds & 228 & 132 & 76 & 78 & 37 & 30 \\
\hline Mean number of records/herd & 39 & 28 & 59 & 14 & 11 & 18 \\
\hline Mean number of sires/herd & 4 & 4 & 7 & 3 & 3 & 4 \\
\hline Sires & 825 & 521 & 557 & 220 & 125 & 125 \\
\hline Mean daughters/sire & 11 & 7 & 8 & 5 & 4 & 4 \\
\hline ME milk yield & 9151 & 8368 & 9854 & 6889 & 6488 & 7246 \\
\hline Standard deviation & 2078 & 1745 & 2137 & 1537 & 1328 & 1688 \\
\hline ME fat yield & 308 & 283 & 330 & 255 & 237 & 270 \\
\hline Standard deviation & 72 & 61 & 75 & 57 & 47 & 62 \\
\hline ME protein yield & 277 & 251 & 300 & 231 & 216 & 244 \\
\hline Standard deviation & 63 & 53 & 64 & 52 & 44 & 56 \\
\hline Score & 3.31 & 3.33 & 3.30 & 3.22 & 3.47 & 3.01 \\
\hline Standard deviation & 1.24 & 1.22 & 1.26 & 1.16 & 1.23 & 1.09 \\
\hline HYSD & 1373 & 1118 & 1653 & 1016 & 875 & 1160 \\
\hline
\end{tabular}

${ }^{1}$ HYSD classes: low $<1330 \mathrm{~kg}$, high $>1370 \mathrm{~kg}$ milk.

${ }^{2}$ HYSD classes: low $<950 \mathrm{~kg}$, high $>990 \mathrm{~kg}$ milk.

Variance component estimates for environments defined by incidence of abnormal lactation or differential use of milk yield-enhancing management practices were similar to the findings from HYSD definitions. Thus, a consistent compression of genetic variance was apparent in low opportunity herds regardless of envi- ronmental definition, but not in the associated heritability estimates (Raffrenato, 2002) due to disproportional changes in residual variances, which agrees with other studies (Boldman and Freeman, 1990; Carvalheira et al., 1998; Cienfuegos-Rivas et al., 1999; Costa et al., 2000; Dong and Mao, 1990; De Veer and Van

Table 3. Sire genetic and residual components of covariance for mature equivalent yields of milk, fat, and protein (kg${ }^{2}$ ), and weighted average somatic cell score for contrasted Friesian herd environments defined by within herd-year standard deviation $\left(\mathrm{HYSD}^{1}\right)$, incidence of abnormal lactation ${ }^{2}$, and differential use of management inputs.

\begin{tabular}{|c|c|c|c|c|c|c|c|c|c|c|c|c|c|}
\hline Trait $^{3}$ & Milk & Fat & Protein & Score & Milk & Fat & Protein & Score & Milk & Fat & Protein & Score & $\begin{array}{l}\text { Variance } \\
\text { component }\end{array}$ \\
\hline & \multicolumn{4}{|c|}{ Low HYSD } & \multicolumn{4}{|c|}{ Abnormal lactation } & \multicolumn{4}{|c|}{ Infrequent use of inputs } & \\
\hline \multirow{3}{*}{$\begin{array}{l}\text { Milk } \\
\text { Fat }\end{array}$} & $1,058,817$ & 27,328 & 26,983 & -97.19 & $1,013,328$ & 28,367 & 26,739 & -99.27 & $1,908,029$ & 50,843 & 51,338 & -133.36 & Residual \\
\hline & & 123 & 73 & 0.44 & & 63 & 50 & 0.63 & & 110 & 45 & 0.51 & Sire \\
\hline & & 1321 & 827 & -3.50 & & 1275 & 861 & -4.33 & & 2507 & 1539 & -4.45 & Residual \\
\hline Protein & & & 76 & 0.18 & & & 69 & 0.04 & & & 57 & 0.28 & Sire \\
\hline \multirow{2}{*}{ Score } & & & & 1.06 & & & & 1.08 & & & & 1.15 & Residual \\
\hline & \multicolumn{4}{|c|}{ High HYSD } & \multicolumn{4}{|c|}{ Normal lactation } & \multicolumn{4}{|c|}{ Frequent use of inputs } & \\
\hline Milk & 121,480 & 1541 & 2831 & -4.41 & 118,838 & 2317 & 3061 & -0.44 & 122,439 & 2364 & 2635 & 0.13 & Sire \\
\hline & $2,105,249$ & 55,561 & 56,032 & -106.67 & $1,778,799$ & 46,431 & 47,059 & -106.55 & $1,471,705$ & 37,989 & 38,039 & -93.57 & Residual \\
\hline Fat & & 255 & 64 & -0.11 & & 177 & 87 & 0.25 & & 118 & 52 & 0.60 & Sire \\
\hline
\end{tabular}

\footnotetext{
${ }^{1}$ Low opportunity $=$ HYSD $<1330 \mathrm{~kg}$ and high opportunity $=$ HYSD $>1370 \mathrm{~kg}$ of milk.

${ }^{2}$ Herds with evidence of peakless lactation for first lactation or older cows were assigned to the abnormal (low opportunity) class. The remaining herds were assigned to the normal lactation (high opportunity) class.

${ }^{3}$ Variances are on the diagonals (bold).
} 
Table 4. Sire genetic and residual components of covariance for mature equivalent yields of milk, fat, and protein ( $\left.\mathrm{kg}^{2}\right)$, and weighted average somatic cell score for contrasted Brown Swiss herd environments defined by within herd-year standard deviation $\left(\right.$ HYSD $\left.^{1}\right)$, incidence of abnormal lactation ${ }^{2}$, and differential use of management inputs.

\begin{tabular}{|c|c|c|c|c|c|c|c|c|c|c|c|c|c|}
\hline Trait $^{3}$ & Milk & Fat & Protein & Score & Milk & Fat & Protein & Score & Milk & Fat & Protein & Score & $\begin{array}{l}\text { Variance } \\
\text { component }\end{array}$ \\
\hline & \multicolumn{4}{|c|}{ Low HYSD } & \multicolumn{4}{|c|}{ Abnormal lactation } & \multicolumn{4}{|c|}{ Infrequent use of inputs } & \\
\hline 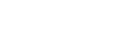 & \multirow{5}{*}{$\begin{array}{r}\mathbf{5 9 , 6 8 9} \\
\mathbf{7 5 6 , 8 4 7}\end{array}$} & \multirow{4}{*}{$\begin{array}{r}2024 \\
24,203 \\
\mathbf{1 1 0} \\
\mathbf{9 9 7}\end{array}$} & 22,985 & -39.43 & 713,317 & 24,349 & 21,373 & 127.37 & 845,052 & 30,507 & 25,418 & -61.91 & Residual \\
\hline Fat & & & 55 & 0.65 & & 130 & 78 & 0.85 & & 90 & 60 & 0.74 & Sire \\
\hline & & & 791 & 0.34 & & 1045 & 785 & -4.74 & & 1286 & 983 & -1.14 & Residual \\
\hline \multirow{2}{*}{ Score } & & & & 1.02 & & & & 0.93 & & & & 0.97 & Residual \\
\hline & & \multicolumn{3}{|c|}{ High HYSD } & \multicolumn{4}{|c|}{ Normal lactation } & \multicolumn{4}{|c|}{ Frequent use of inputs } & \\
\hline Milk & 90,151 & 2717 & 3208 & 13.52 & 73,247 & 2781 & 2690 & 13.15 & 71,876 & 1893 & 1688 & 29.34 & Sire \\
\hline & 915,070 & 30,577 & 27,259 & -50.23 & 976,855 & 31,679 & 29,806 & -143.07 & 909,516 & 27,275 & 26,827 & -47.13 & Residual \\
\hline Fat & & 106 & 102 & -0.01 & & 136 & 115 & 0.01 & & 94 & 49 & 0.46 & Sire \\
\hline
\end{tabular}

${ }^{1}$ Low opportunity $=$ HYSD $<950 \mathrm{~kg}$ and high opportunity $=$ HYSD $>990 \mathrm{~kg}$ of milk.

${ }^{2}$ Herds with evidence of peakless lactation for first lactation and older cows were assigned to the abnormal (low opportunity) class. The remaining herds were assigned to the normal lactation (high opportunity) class.

${ }^{3}$ Variances are on the diagonals (bold).

Vleck, 1987; Meinert et al., 1988; Short et al., 1990; Stanton et al., 1991b).

Weighted somatic cell score. Sire and residual covariances for weighted somatic cell score (Table 3) were similar between high and low Friesian environments, except for the possible smaller genetic variation with frequent abnormal lactation. Heritabilities in contrasting HYSD environments were 0.10 in both breeds (Raffrenato, 2002), which agreed with findings by Castillo-Juarez and co-workers (2000). Genetic correlations between score and yield traits were slightly favorable in high HYSD Friesian herds (range: -0.16 to -0.04 ), but they tended to be antagonistic in the low HYSD environments in both breeds (range: 0.02 to 0.42 ). Therefore, besides yield performance, genetic expression of weighted somatic cell score may also be affected in low opportunity environments.

\section{Between-Environment Analysis}

Multivariate analyses revealed important differences in genetic components of variance in differentiated environments. Therefore, estimates from bivariate analyses helped to further evaluate the expected impact of $\mathrm{G} \times \mathrm{E}$ on opportunity loss, or sacrifice, in genetic gain in the most restrictive environments. The resulting components of covariance for all definitions of low and high opportunity Friesian environments with heritabilities and genetic correlations for HYSD environments are in Table 5, and in Raffrenato (2002) for Brown Swiss herds.

HYSD environments. Sire variances for yield traits in both breeds were consistently smallest in the low opportunity environments, while estimates for somatic cell score were similar in the contrasted environments. Therefore, discussion focuses on results from the more plentiful Friesian data.

Sire and residual variance components for milk yield from low HYSD Friesian herds were about half as large as corresponding estimates from the high HYSD environment (Table 5). The genetic correlation $(0.63)$ between these environments differed from unity $(P<0.0001)$ and was similar to the correlation in first-lactation milk yield between herds in the US and Mexico (Cienfuegos-Rivas et al., 1999), which suggests major re-ranking of sire breeding values. Components of variance for yields of fat and protein showed the same pattern. Genetic correlations between environments were 0.66 for fat and 0.48 for protein, both less than unity $(P<0.0001)$, also signaling substantial re-ranking in breeding values. Like the multivariate analysis sire and residual variances and the heritability of weighted somatic cell score $(0.10)$ were similar in the contrasted environments.

Incidence of abnormal lactation. A similar pattern of response in yield traits was found, where genetic variation was less in herds with abnormal (peakless) lactation either in primiparous or pluriparous cows. Genetic varia- 


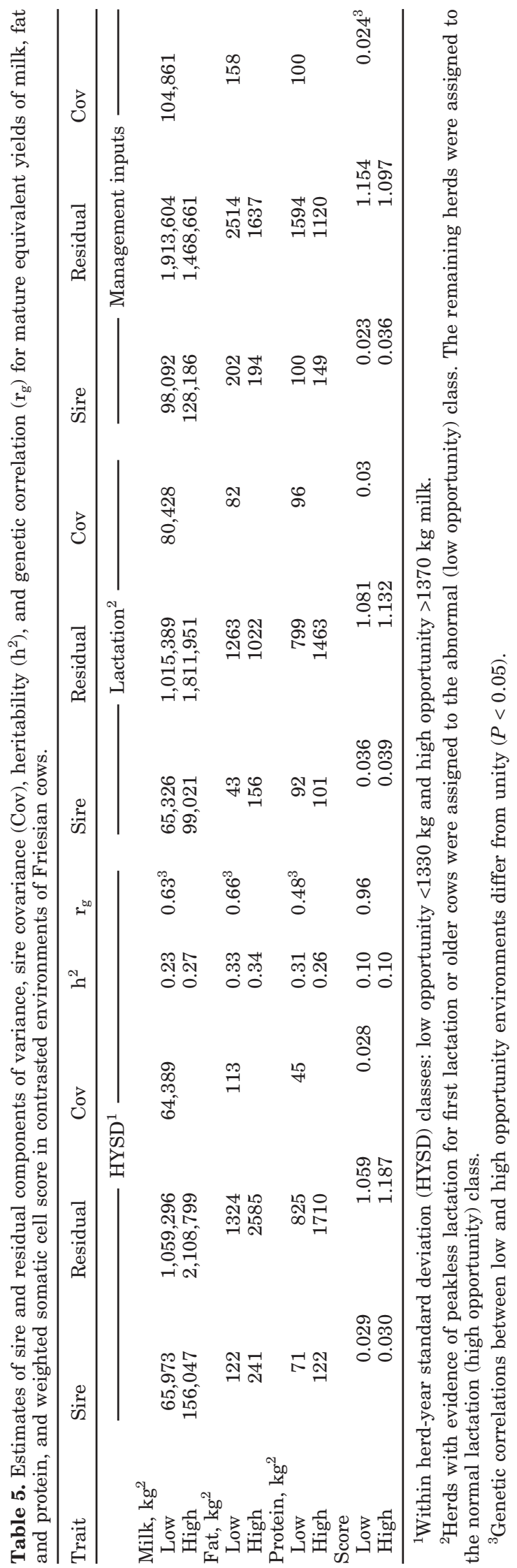

tion was also compressed in low opportunity Brown Swiss herds (Raffrenato, 2002). These diminished responses may have been caused by too few nutritional and health inputs and disrupted homeorhetic pathways (physiological orchestration) in the early postpartum period. Genetic correlations between environments were large and positive (range: 0.95 to 0.99 ), indicating no important effect on the ranking of sire values. Sire variances for weighted somatic cell score were similar with no important change in breeding values indicated by the genetic correlations.

Differential management practices. As for other definitions of contrasting environments, the sire component of variance for milk yield was also smaller in Friesian herds where nutritional and udder health inputs and practices were used relatively infrequently. This finding is consistent with the result from multivariate analysis for this definition (Table 3). Less genetic variation also occurred in protein yield, but genetic variances were similar for yield of fat. Sire variances for yield traits of Brown Swiss cows also were least in the low input environment (Raffrenato, 2002).

Importantly, the sire variance for weighted somatic cell score in the low opportunity environment (both breeds) was less than in herds relying on more management (e.g., udder health). Consequently, the genetic correlation between environments differed from unity $\left(\mathrm{r}_{\mathrm{g}}=\right.$ $0.83, P<0.05$ ), indicating re-ranking in breeding values. Thus, differentiation of production environments based on our survey of management inputs and environmental clustering was effective in identifying heterogeneous genetic expression in these herds.

Overall, discriminating herd environments by any of these definitions, including the endogenous HYSD variable, revealed a consistent pattern of unequal genetic expression, or $\mathrm{G} \times \mathrm{E}$, in yield traits. Furthermore, evidence was also found for $\mathrm{G} \times \mathrm{E}$ in weighted somatic cell score in both breeds. Collectively, this information indicates that the $\mathrm{G} \times \mathrm{E}$ occurring in about one-half of the dairy herds in Sicily's principal dairy region is mainly from compression in genetic expression fostered by input constraints.

\section{Correlated Response and Genetic Trend}

Compression in sire components of variance translates into diminished genetic gain from selection in low opportunity environments compared to herds with fewer limitations. The expected correlated responses in these environments for Friesian and Brown Swiss are in Table 6. Estimates generally indicate $20 \%$ to $60 \%$ less genetic gain in milking performance from indirect selection based on information from more privileged environments. 
Table 6. Expected correlated responses in yields of milk, fat and protein, and weighted somatic cell score in the low opportunity environments as a proportion (genetic regression) of response in the high opportunity environments defined by herd-year standard deviation (HYSD), incidence of abnormal lactation, and differential use of yieldenhancing management inputs.

\begin{tabular}{|c|c|c|c|c|}
\hline Environmental criterion & Milk & Fat & Protein & Score \\
\hline & \multicolumn{4}{|c|}{ Friesian } \\
\hline HYSD < $1330 \mathrm{~kg}$ & 0.41 & 0.46 & 0.36 & 0.93 \\
\hline Abnormal lactation & 0.81 & 0.52 & 0.95 & 0.92 \\
\hline \multirow[t]{2}{*}{ Infrequent use of inputs } & 0.81 & 0.81 & 0.67 & 0.66 \\
\hline & \multicolumn{4}{|c|}{ Brown Swiss } \\
\hline HYSD $<950 \mathrm{~kg}$ & 0.75 & 0.53 & 0.43 & 0.68 \\
\hline Abnormal lactation & 0.80 & 0.85 & 0.79 & 0.84 \\
\hline Infrequent use of inputs & 0.67 & 0.86 & 0.82 & 0.61 \\
\hline
\end{tabular}

Coefficients of expected correlated response for yield traits in the low HYSD environments for both breeds were smallest among our definitions. Sacrifices in yield response in these environments, relative to less constrained alternatives, were about one-half for Friesian and one-fourth to one-half for Brown Swiss. Less response was also predicted in herds with greatest abnormal (peakless) lactation and in herds with least frequent use of recommended nutrition, milking and udder health inputs (except protein yield in Friesian herds with abnormal lactation).

The expected correlated response in somatic cell score for both breeds was similarly depressed about $30 \%$ in herds with relatively little milk yield-enhancing management. This outcome may be due to less use of recommended udder health and milking practices. Coefficients for the other environmental definitions exceeded 0.80, except in low HYSD Brown Swiss herds.

Less sire variation in low opportunity environments reduced the expected selection response in both breeds, regardless of the definition. This result is consistent with findings from around the world (Boldman and Freeman, 1990; Carvalheira et al., 1998; Castillo-Juarez et al., 2000; Cienfuegos-Rivas et al., 1999; Costa et al., 2000; Dong and Mao, 1990; De Veer and Van Vleck, 1987; Meinert et al., 1988; Short et al., 1990; Stanton et al., 1991b) that unequal genetic progress and, thus, unequal net economic returns from genetic decisions are functions of identifiable input constraints. Net economic returns are depressed and optimal decisions are altered by diminished daughter milk response and predisposing environmental limitations (Blake, 1992; Holmann et al., 1990). Greater and more rapid genetic improvement in productivity and larger net economic payoffs would be expected by ameliorating the restrictions that foster $\mathrm{G} \times \mathrm{E}$, including the ones in this study to identify low opportunity herds.

Figure 1 shows genetic trends for milk yield for Friesian (panels a and b) and Brown Swiss (panels c and d) in the contrasting environments defined by incidence of abnormal lactation and the use frequency of management inputs to increase milk yield. Genetic trends in herds with frequent abnormal lactation were inferior to those in environments with normal lactation, undoubtedly due to less expression of genetic variation in these herds. Annual trends with low inputs were mostly smaller than in less constrained environments.

The estimated average annual genetic gain was $20 \mathrm{~kg}$ milk for Friesian cows born from 1991 to 1997. This was similar to the $24 \mathrm{~kg} / \mathrm{yr}$ gain in Brazilian Holstein (Costa et al., 1998), but inferior to gains of $57 \mathrm{~kg} / \mathrm{yr}$ (1974 to 1984 ) and $173 \mathrm{~kg} / \mathrm{yr}$ (1985 to 1988) reported in average Italian Friesian herds (Burnside et al., 1992). The sire components of variance for Brown Swiss yield traits in our study averaged 50\% less than estimates from a sirematernal grandsire model applied to the Italian Brown Swiss population (Santus et al., 1993), which resulted in $8 \mathrm{~kg}$ annual genetic gain in milk. Smaller variances and genetic gain in southeastern Sicily may have resulted from fewer management inputs than in average Italian herds in both breeds.

Positive genetic trends in alternative environments in both breeds indicated farmers' attention to sire selection. The differences between environments in annual genetic change for yield traits were consistently positive across criteria, which demonstrate the greater returns from selection that accrue in the more favorable environments. Annual genetic gain in weighted somatic cell score was positive but close to zero in every environmental definition.

\section{CONCLUSIONS}

A set of definitions of contrasting herd environments was applied to study genetic expression in yields of milk and milk components and weighted somatic cell score of Friesian and Brown Swiss cows in the principal dairy region of Sicily. The HYSD definition was a proxy for herd management, assuming that more effective management begets greater performance variability within a herd. Unfortunately, this criterion utilizes an endogenous variable potentially correlated with milk yield response (i.e., the "outcome"), which can potentially bias the resulting inferences. The incidence of abnormal lactation contains much less of this potential bias because fewer test days are required to detect ascent to a maximum daily milk yield, itself a management-responsive biological input to overall performance. Differentiated sets of managementclustered herds relied on exogenous information about input use to discriminate productive opportunities in a manner independent of the data (i.e., outcomes).

These definitions revealed consistent unequal responses in contrasting high and low opportunity environ- 

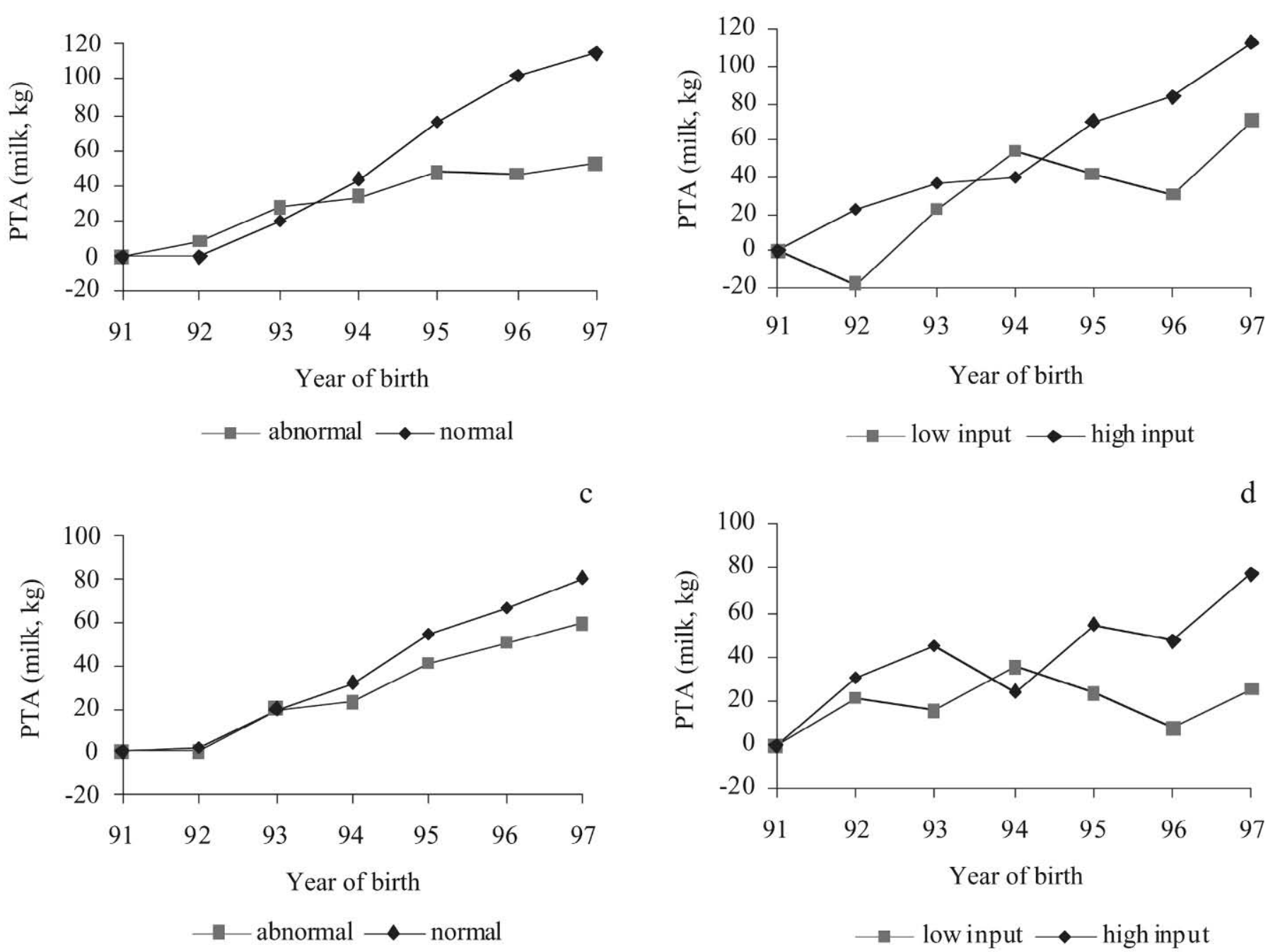

c
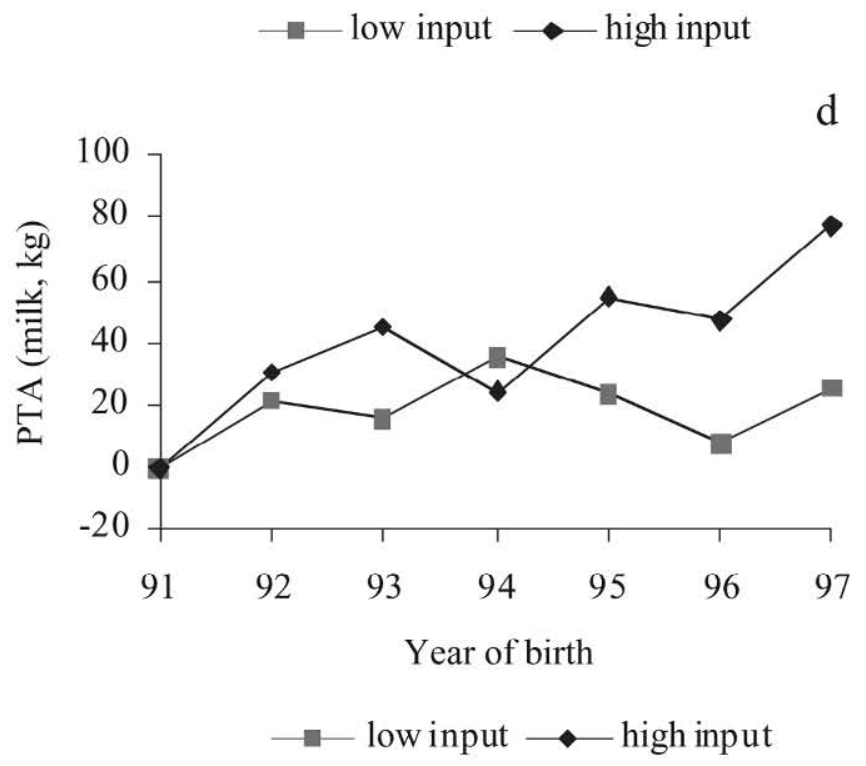

Figure 1. Genetic trend in average predicted transmitting ability (PTA) for milk of Friesian (a and b) and Brown Swiss (c and d) sires weighted by number of daughters in herds differing by frequency of abnormal lactation and use frequency of management inputs.

ments. Sire and residual variances for all traits were typically smaller in the low opportunity environments for within- and between-environment analyses. Heritability estimates for yield traits and for somatic cell score with these definitions were similar to those from previous reports. In general, genetic correlations were less favorable in the low opportunity environments. Antagonistic genetic correlations between yield traits and somatic cell score may have been attenuated by greater inputs in the high opportunity herds.

Except for the HYSD definition, genetic correlations between contrasted environments were near unity for yields of milk, fat and protein, indicating similar genetic controls. However, as in other studies relying on endogenous definition, compressed variance in breeding values (i.e., scaling effect) rather than change in rank was the key evidence for $\mathrm{G} \times \mathrm{E}$. The expected correlated responses in yield traits were about $40 \%$ less in low opportunity herds when selection was based on information from more privileged environments. Furthermore, small correlated responses in somatic cell score in both breeds were detected in environments with infrequent use of preferred management, including udder health and milking procedure. This is additional evidence for environmental restriction of genetic expression (variation), which signifies less gain from selection regardless of specific selection goals.

Ideally, it would be best to cluster herds using exogenous information, as in this study. Nonetheless, findings clearly showed that the consequences are not severe 
when using HYSD to differentiate environments. Contrasting environments defined by the incidence of peakless lactation has potential advantages because nutritional and health inputs and homeorhetic mechanisms control or predispose this behavior. An appealing alternative, because it would be easy to implement, would be to depict herd responses as a continuous environmental gradient (reaction norm) of normal and peakless lactation curves using $b$ parameter solutions (or their lower confidence limits) from the incomplete gamma function.

\section{ACKNOWLEDGMENTS}

This project was partially funded by CoRFiLaC (Ragusa, Italy) and Cornell University. The data were kindly provided by Associazione Nazionale Frisona Italiana, Associazione Nazionale Allevatori Razza Bruna, and CoRFiLaC. We especially thank the technical staff of CoRFiLaC for assistance in conducting the survey. The help of the Associazione Provinciale Allevatori of Ragusa is also gratefully acknowledged.

\section{REFERENCES}

Blake, R. W. 1992. Genetic decisions with current economic indexes. Pages 26-35 in Large Dairy Herd Management. ADSA, Champaign, IL.

Boldman, K. G., and A. E. Freeman. 1990. Adjustments for heterogeneity of variances by herd level in dairy cows and sire evaluation. J. Dairy Sci. 73:503-512.

Burnside, E. B., G. B. Jansen, G. Civati, and E. Dadati. 1992. Observed and theoretical genetic trends in a large dairy population under intensive selection. J. Dairy Sci. 75:2242-2253.

Carvalheira, J. G. V., R. W. Blake, E. J. Pollak, R. L. Quaas, and C. V. Duran-Castro. 1998. Application of an autoregressive process to estimate genetic parameters and breeding values for dairy milk yield in a tropical herd of Lucerna cattle and in US Holstein herds. J. Dairy Sci. 81:2738-2751.

Castillo-Juarez, H., P. A. Oltenacu, R. W. Blake, C. E. McCulloch, and E. G. Cienfuegos-Rivas. 2000. Effect of herd environment on the genetic and phenotypic relationships among milk yield, conception rate, and somatic cell score in Holstein cattle. J. Dairy Sci. 83:807-814.

Cienfuegos-Rivas, E. G., P. A. Oltenacu, R. W. Blake, S. J. Schwager, H. Castillo-Juarez, and F. J. Ruiz. 1999. Interaction between milk yield of Holstein cows in Mexico and the United States. J. Dairy Sci. 82:2218-2223.

Costa, C. N. 1998. Genetic relationship for milk and fat yields between Brazilian and United States Holstein cattle populations. Ph.D. Dissertation. Department of Animal Science. Cornell University, Ithaca, NY. 175 pp.

Costa, C. N., R. W. Blake, E. J. Pollak, P. A. Oltenacu, R. L. Quaas, and S. R. Searle. 2000. Genetic analysis of Holstein cattle populations in Brazil and the United States. J. Dairy. Sci. 83:2963-2974.

DeJager, D., and B. W. Kennedy. 1987. Genetic parameters of milk yield and composition and their relationships with alternative breeding goals. J. Dairy Sci. 70:1258-1266.

Dong, M. C., and I. L. Mao. 1990. Heterogeneity of covariance and heritability in different levels of intraherd milk production variance and of herd average. J. Dairy Sci. 73:843-851.

Holmann, F. J., R. W. Blake, R. A. Milligan, R. Barker, P. A. Oltenacu, and M. V. Hahn. 1990. Economic returns from US artificial insemi- nation sires in Holstein herds in Colombia, Mexico, and Venezuela. J. Dairy Sci. 73:2179-2189.

Jones, G. M., R. E. Pearson, G. A. Clabaugh, and C. W. Heald. 1984. Relationships between somatic cell counts and milk production. J. Dairy Sci. 67:1823-1831.

Kolmodin, R., E. Strandberg, P. Madsen, J. Jensen, and H. Jorjani. 2002. Genotype by environment interaction in Nordic dairy cattle studied using reaction norms. Acta Agric. Scand. 52:11-24.

Kuo, A. 1997. The Distance Macro: Preliminary documentation, 2nd ed. Multivariate and Numerical R \& D. Application Division SAS Institute Inc., Cary, NC.

Lance, G. N., and W. T. Williams. 1967. A general theory of classificatory sorting strategies. I. Hierarchical. Computer Journal 9:373380.

Licitra, G., R. W. Blake, P. A. Oltenacu, S. Barresi, S. Scuderi, and P. J. Van Soest. 1998. Assessment of the dairy production needs of cattle owners in southeastern Sicily. J. Dairy Sci. 81:2510-2517.

Manfredi, E. J., R. W. Everett, and S. R. Searle. 1984. Phenotypic and genetic statistics of components of milk and two measures of somatic cell concentration. J. Dairy Sci. 67:2028-2033.

Meinert, T. R., R. E. Pearson, W. E. Vinson, and B. G. Cassel. 1988. Effect of within-herd variance and herd-mean production on response to selection within herd. J. Dairy Sci. 71:3405-3414.

Meinert, T. R., R. E. Pearson, W. E. Vinson, and R. S. Hoyt. 1992. Estimates of genetic trend in artificial insemination progeny test program and their association with herd characteristics. J. Dairy Sci. 75:2254-2264.

Milligan, G. W. 1989. A Study of the Beta-Flexible Clustering Method. Multivariate Behavioral Research 24:163-176.

Raffrenato, E. 2002. Heterogeneous genetic variation in yields of milk and milk components in alternative herd environments of HolsteinFriesian and Brown Swiss cows in Southeastern Sicily. M.S. Thesis. Department of Animal Science. Cornell University, Ithaca, NY. $156 \mathrm{pp}$.

Roman, R. M., and C. J. Wilcox. 2000. Bivariate animal model estimates of genetic, phenotypic, and environmental correlations for production, reproduction, and somatic cells in Jerseys. J. Dairy Sci. 83:829-835.

Santus, E. C., R. W. Everett, R. L. Quaas, and D. M. Galton. 1993. Genetic parameters of Italian Brown Swiss for levels of herd yield. J. Dairy Sci. 76:3594-3600.

Schutz, M. M, L. B. Hansen, G. R. Steuernagel, J. K. Reneau, and A. L. Kuck. 1990. Genetic parameters for somatic cells, protein and fat in milk of Holsteins. J. Dairy Sci. 73:494-502.

Seykora, A. J., and B. T. McDaniel. 1983. Heritabilities and correlations of lactation yields and fertility for Holsteins. J. Dairy Sci. 66:1486-1493.

Short, T. R., R. W. Blake, R. L. Quaas, and L. D. Van Vleck. 1990. Heterogeneous within-herd variance. 1. Genetic parameters for first and second lactation milk yields of grade Holstein cows. J. Dairy Sci. 73:3312-3330.

Stanton, T. L., R. W. Blake, R. L. Quaas, and L. D. Van Vleck. 1991a. Response to selection of US Holstein sires in Latin America. J. Dairy Sci. 74:651-664.

Stanton, T. L., R. W. Blake, R. L. Quaas, L. D. Van Vleck, and M. J. Carabano. 1991b. Genotype by environment interaction for Holstein milk yield in Colombia, Mexico and Puerto Rico. J. Dairy Sci. 74:1700-1714.

Weigel, K. A., and R. Rekaya. 2000. A multiple-trait herd cluster model for international dairy sire evaluation. J. Dairy Sci. 83:815-821.

Welper, R. D., and A. E. Freeman. 1992. Genetic parameters for yield traits of Holstein, including lactose and somatic cell score. J. Dairy Sci. 75:1342-1348.

Wood, P. D. P. 1967. Algebraic model of the lactation curve in cattle. Nature. 216:164-165.

Zwald, N. R., K. A. Weigel, W. F. Fikse, and R. Rekaya. 2001. Characterization of dairy production systems in countries that participate in the international bull evaluation service. J. Dairy Sci. 84:2530-2534. 